\title{
Global Forum of Cancer Surgeons: Cancer Surgery During the COVID-19 Pandemic: Impact and Lessons Learned
}

\author{
Chandrakanth Are, MBBS, MBA, FSSO, FRCS, FACS ${ }^{1}$, D. Tyler, MD, FSSO ${ }^{1}$, J. Howe, MD, FSSO ${ }^{1}$, \\ A. Olivares ${ }^{1}$, A. Nissan, MD ${ }^{2}$, D. Zippel, MD, FACS ${ }^{2}$, A. Gupta, MBBS, FRCS ${ }^{3}$, D. Savant, MBBS ${ }^{3}$, \\ D. D'Ugo, $\mathrm{MD}^{4}$, I. Rubio, $\mathrm{MD}^{4}$, J. E. Bargallo-Rocha, $\mathrm{MD}^{5}$, H. Martinez-Said, $\mathrm{MD}^{5}$, H. Takeuchi, $\mathrm{MD}^{6}$, \\ A. Taketomi, $\mathrm{MD}^{6}$, A. F. Oliveira, $\mathrm{MD}, \mathrm{PhD}^{7}$, H. S. Castro Ribeiro, MD, $\mathrm{PhD}^{7}$, M. A. Cheema, MD, $\mathrm{FRCS}^{8}$, \\ H. J. Majid, MD, FRCS ${ }^{8}$, G. Chen, MD , F. Roviello, MD $^{10}$, A. Gronchi, MD ${ }^{10}$, A. Leon, MD, MSCCh ${ }^{11}$, \\ W. Y. Lee, MD, PhD ${ }^{12}$, D. J. Park, MD, PhD ${ }^{12}$, J. Park, MD ${ }^{13}$, R. Auer, $\mathrm{MD}^{13}$, W. A. Gawad, MD, PhD ${ }^{14}$, and \\ A. Zaghloul, $\mathrm{MD}^{14}$
}

${ }^{1}$ Society of Surgical Oncology, Rosemont, IL; ${ }^{2}$ Israeli Society of Surgical Oncology, Tel Aviv, Israel; ${ }^{3}$ Indian Association of Surgical Oncology, Uttar Pradesh, Varanasi, India; ${ }^{4}$ European Society of Surgical Oncology, Brussels, Belgium;

${ }^{5}$ Sociedad Mexicana de Oncologia, Mexico City, Mexico; ${ }^{6}$ Japanese Society of Gastroenterological Surgery, Tokyo, Japan; ${ }^{7}$ Brazilian Society of Surgical Oncology, Rio de Janeiro, Brazil; ${ }^{8}$ Pakistan Society of Surgical Oncology, Lahore, Pakistan; ${ }^{9}$ Chinese Society of Clinical Oncology, Beijing, China; ${ }^{10}$ Italian Society of Surgical Oncology, Milan, Italy; ${ }^{11}$ Pontifical Catholic University of Chile, Santiago, Chile; ${ }^{12}$ Korean Society of Surgical Oncology, Seoul, Korea; ${ }^{13}$ Canadian Society of Surgical Oncology, Ottawa, ON, Canada; ${ }^{14}$ Egyptian Society of Surgical Oncology, Cairo, Egypt

\begin{abstract}
Background. The purpose of this article is to summarize the opinions of the surgical oncology leaders from the Global Forum of Cancer Surgeons (GFCS) about the global impact of COVID-19 pandemic on cancer surgery.

Methods. A panel session (virtual) was held at the annual Society of Surgical Oncology 2021 International Conference on Surgical Cancer Care to address the impact of COVID-19 on cancer surgery globally. Following the virtual meeting, a questionnaire was sent to all the leaders to gather additional opinions. The input obtained from all the leaders was collated and analyzed to understand how cancer surgeons from across the world adapted in real-time to the impact of COVID-19 pandemic.
\end{abstract}

D. Savant: Deceased.

(C) Society of Surgical Oncology 2022

First Received: 24 November 2021

Accepted: 14 February 2022;

Published Online: 24 February 2022

C. Are, MBBS, MBA, FSSO, FRCS, FACS

e-mail: care@unmc.edu
Results. The surgical oncology leaders noted that the COVID-19 pandemic led to severe disruptions in surgical cancer care across all domains of clinical care, education, and research. Several new changes/protocols associated with increased costs were implemented to deliver safe care. Leaders also noted that preexisting disparities in care were exacerbated, and the pandemic had a detrimental effect on well-being and financial status.

Conclusions. The COVID-19 pandemic has led to severe disruptions in surgical cancer care globally. Leaders of the GFCS opined that new strategies need to be implemented to prepare for any future catastrophic events based on the lessons learned from the current events. The GFCS will embark on developing such a roadmap to ensure that surgical cancer care is preserved in the future regardless of any catastrophic global events.

Since its emergence in late 2019, the SARS-CoV-2-related, COVID-19 pandemic has infected more than 245 million people. ${ }^{1}$ To date, it is estimated that approximately 5 million deaths are related to the COVID-19 pandemic. ${ }^{1}$ Some believe that the actual death toll may be higher, attributable to insufficient or incorrect reporting of COVID-19 cases in many parts of the world. ${ }^{2}$ The genetic 
lineage of SARS-CoV-2 virus has led to the emergence of multiple variants, some of which have been more lethal than the original virus. ${ }^{3}$ It is likely that SARS-CoV-2 virus and its evolutionary variants will continue to add to the incrementally accumulating burden of this disease.

The COVID-19 pandemic has had a grave impact on every facet of life with catastrophic consequences for the entire world. ${ }^{1}$ The brunt of this impact has been felt the most in the field of health care with interruptions in care delivery and adverse consequences to both patients and caregivers. $^{4-6}$ The World Health Organization (WHO) conducted a rapid assessment survey of service delivery for noncommunicable diseases during the first wave of the pandemic in $2020 .^{4}$ The survey was conducted between May 1-25, 2020 and involved 194 Ministries of Health across the world. Nearly 122 countries reported that they noted disruptions in services for many noncommunicable diseases. Disruptions (partial or complete) in cancer delivery services were reported by approximately $42 \%$ of the responding countries. Approximately $5 \%$ of the countries noted complete interruptions.

Riera et al. conducted a systematic review of studies to specifically identify, categorize, and estimate the frequency of delays and disruptions in global cancer health care due to the COVID-19 pandemic. ${ }^{5}$ Despite lacking high methodological quality, the included 62 studies identified multiple and severe disruptions along the entire chain of cancer care delivery. Treatment delays (26-62.4\%), treatment interruption $(77.5 \%)$, change in treatment plan (1.6-82\%), and reduction in cancer treatment (42\%) were noted by the authors. Specific to surgical care, treatment delay (3.34-76\%), treatment interruption (30-80\%), and reduction of the number of surgeries $(14.28-85.8 \%)$ were documented across the world.

The impact of COVID-19 on cancer with a specific focus on surgical care was analyzed by the COVIDSurg Collaborative. $^{6}$ This international, prospective, cohort study was conducted in 2020 by obtaining data from 466 hospitals in 61 countries across the world. The authors sought to analyze the impact of COVID-19 on disruptions in surgical cancer care for 15 solid organ cancer types and included 20,006 patients. Of all the eligible patients, nearly $10 \%$ of the patients did not receive surgery after a median follow-up of 23 weeks. The level of interruptions in cancer surgical care varied based on several factors, such as the stringency of lockdowns (low, medium, and high) and income status (based on World Bank Index: high-income countries, upper middle-income countries, and low-tomiddle-income countries) of the respective countries.

The Global Forum of Cancer Surgeons (GFCS) was formed in 2017 to advance the goals of cancer surgery on the global stage. ${ }^{7,8}$ The mission of the GFCS is to provide a voice for cancer surgeons to improve surgical care for cancer patients through multidisciplinary clinical care, education, research, outreach advocacy, and leadership on the global stage. ${ }^{9}$ The GFCS consists of surgical oncology leaders from 15 reputable surgical oncology societies across the world. These societies with their respective leaders represent more than $75 \%$ of the global cancer burden by incidence and mortality.

The GFCS, in its nascent stages, has strived to advocate for cancer surgery on the global stage through several initiatives. Some of the initiatives include addressing the barriers to cancer surgery ${ }^{10}$ and promoting the benefits ${ }^{11}$ of safe and timely cancer surgery. The GFCS also has been involved in addressing specific issues relating to cancer surgery in specific countries. One such initiative included collaboration with the Brazilian Society of Surgical Oncology (BSSO) and other bodies to successfully lobby the Brazilian government to include cytoreductive surgery/hyperthermic intraperitoneal chemotherapy in the Brazilian Public Health System (Sistema Único de Saúde, or SUS). ${ }^{12}$

As expected, the emergence of SARS-CoV-2 virus prompted the leaders of the GFCS to discuss the adverse ramifications of the COVID-19 pandemic on cancer surgery globally. The purpose of this article is to summarize the opinions of the surgical oncology leaders of the GFCS about the impact of the COVID-19 pandemic on cancer surgery on the global stage.

\section{METHODS}

A panel session (virtual) was held at the annual Society of Surgical Oncology 2021 International Conference on Surgical Cancer Care to address the impact of COVID-19 on the global stage. This session (Cancer Surgery During a Pandemic: A Global Perspective) sought to obtain the opinions of global cancer surgery leaders about the impact of COVID-19 on the various domains of cancer surgical care. Following the virtual meeting, a questionnaire was sent to all the leaders to gather additional opinions regarding the impact of the COVID-19 pandemic on cancer surgery. Opinions were sought on the various domains of cancer surgical care ranging from: clinical care, education, research, well-being, effect of inequities, impact on financial situation, etc. The input obtained from all the leaders was collated and analyzed to understand how cancer surgeons from across the world adapted to the impact of the COVID-19 pandemic. 
TABLE 1 Interruptions in cancer surgery and cancers most affected

\begin{tabular}{lll}
\hline Country/region & Canceled elective cancer surgery: yes/no & Cancer sites most affected \\
\hline Brazil & Yes (March/April 2020) & Breast/colorectal/cervix/prostate \\
Canada & Yes (Variable time periods based on successive waves: from & Breast/GI/colorectal/lung/GU/ovarian \\
& April 2020 to September 2021) & \\
Chile & Yes (April to July 2020) & Skin/breast/thyroid \\
China & Yes (February to April 2020) & Lung/thyroid \\
Egypt & Yes (March to May 2020) & Breast/Colorectal/Bladder \\
Europe & Yes (March to May 2020) & Breast/colon \\
India & Yes (approximately 6 weeks during first lockdown) & Pancreas/head \& neck/breast/colorectal/thoracic \\
Israel & No & Delays in screening for breast/colorectal \\
Italy & No & Colorectal/pancreas/sarcoma \\
Japan & Yes (only during first wave: April to May 2020_approximately & Colorectal/gastric/lung \\
& $10 \%$ cancellation) & \\
Republic of Korea & No & Gastrointestinal/lung/hepatobiliary/pancreas \\
Mexico & Yes (2 weeks) & Gastrointestinal/lung \\
Pakistan & Yes (delayed for 11 months from February to December 2020) & Breast/colorectal/gastroesophageal junction \\
United States of America & Yes, for varying periods during 2020 and 2021 & Breast/colon/prostate/pancreas/endocrine \\
\hline
\end{tabular}

\section{RESULTS}

Findings about interruptions in cancer surgery (canceled elective cancer surgery) and cancers most affected are documented in Table 1. The majority of the leaders (76\%) noted that elective cancer surgical cases were canceled as a result of the pandemic. The most common time period for cancellation of elective cancer surgical cases was during the first half of 2020. Leaders from Israel, Italy, and Republic of Korea did not document cancellation of elective cancer surgical cases. Although nearly all cancer sites were affected, the most common cancers affected by the pandemic were related to breast, colorectal, thyroid, and gastrointestinal cancers. Despite not cancelling elective cancer surgical cases, leaders from Israel, Italy, and Republic of Korea noted an adverse impact on cancer care related to breast, colorectal, gastrointestinal, and other malignancies.

Changes/new protocols implemented in the perioperative setting to accommodate for the COVID-19 pandemic are documented in Table 2. The common adaptive themes that emerged from the preoperative setting included: enhanced screening for COVID-19 with near universal use of RT-PCR testing and other investigations, reducing surgical procedures (particularly complex procedures) or shifting to an ambulatory setting where feasible, minimizing procedures that may need stay in the Intensive Care Unit (ICU), triaging patients for procedures, categorizing risk status for potential COVID-19 infection, and restrictive visitor policies.
In the intraoperative setting, the most common changes consisted of: use of Personal Protective Equipment (PPE) and following universal precautions, avoiding or modifying laparoscopic procedures to minimize aerosolization, avoiding or minimizing other aerosol-generating procedures, special precautions during intubation and extubation, minimizing the number of personnel in the operating room (OR), dedicating particular ORs for patients with COVID-19, and modifications to other OR equipment (electrocautery, suction, etc.).

In the postoperative setting, the changes and new policies focused on: early discharge, implementation of Early Recovery After Surgery (ERAS) protocols, restrictive visitor policies, continued vigilance with retesting for COVID-19 patients as needed, and modifying nursing care patterns to minimize visitors.

\section{Availability of PPE}

The majority of the respondents noted that they faced shortages of PPE to varying degrees (mild to severe, requiring adaptation in some cases by using raincoats under surgical gowns, etc.) during the early stages of the pandemic. Over the course of 2020 and later, nearly all reached sufficiency with PPE from a combination of enhanced local production or importing from other countries.

\section{Impact on Long-Term Oncological Outcomes}

The majority of leaders noted that the disruptions to surgical cancer care due to the pandemic will affect the long-term prognosis at the individual and population level. 
TABLE 2 Changes/new protocols implemented in the peri-operative setting to accommodate for the COVID-19 pandemic

\begin{tabular}{|c|c|c|c|}
\hline $\begin{array}{l}\text { Country/ } \\
\text { region }\end{array}$ & Preoperative & Intraoperative & Postoperative \\
\hline Brazil & $\begin{array}{l}\text { 1. Screening for cases with contact or } \\
\text { symptoms of COVID-19 } \\
\text { 2. Rational use of RT-PCR testing (due } \\
\text { to shortage) } \\
\text { 3. Pre-operative self-isolation }\end{array}$ & $\begin{array}{l}\text { 1. Universal use of PPE for all } \\
\text { 2. Avoid AGP procedures including some } \\
\text { laparoscopic procedures } \\
\text { 3. Special filters to deflate pneumoperitoneum } \\
\text { 4. Dedicated COVID-19 operating rooms }\end{array}$ & $\begin{array}{l}\text { 1. Early discharge } \\
\text { 2. ERAS protocols }\end{array}$ \\
\hline Canada & $\begin{array}{l}\text { 1. Protocols to triage patients for surgery } \\
\text { 2. Screening protocols to assess risk of } \\
\text { COVID-19 (green= low risk/ } \\
\text { orange }=\text { high risk/red = confirmed case } \\
\text { of COVID-19) } \\
\text { 3. COVID-19 testing if symptoms }\end{array}$ & $\begin{array}{l}\text { 1. Early on: PPE and universal precautions } \\
\text { for all and mandatory time between cases } \\
\text { to allow for air exchange } \\
\text { 2. Later: PPE and universal precautions based } \\
\text { on risk from Screening protocols }\end{array}$ & $\begin{array}{l}\text { 1. Restricted visitor policy } \\
\text { 2. Recovery after extubation in the } \\
\text { OR due to PACU nurse shortage }\end{array}$ \\
\hline Chile & $\begin{array}{l}\text { 1. Eliminate complex surgical } \\
\text { procedures } \\
\text { 2. Shift to ambulatory surgery when } \\
\text { feasible }\end{array}$ & $\begin{array}{l}\text { 1. Focus on low-complexity surgical } \\
\text { procedures }\end{array}$ & 1. Early discharge \\
\hline China & $\begin{array}{l}\text { 1. Infection screening with COVID-10 } \\
\text { tests }\end{array}$ & - & - \\
\hline Egypt & $\begin{array}{l}\text { 1. Consider possible alternative } \\
\text { treatment: neoadjuvant therapy } \\
\text { 2. ERAS protocols } \\
\text { 3. Admission only on day of surgery } \\
\text { 4. For those that need pre-operative } \\
\text { admission, application of stringent } \\
\text { criteria } \\
\text { 5. Specific pre-operative clearance } \\
\text { clinics } \\
\text { 6. Virtual clinics to update treatment } \\
\text { plans } \\
\text { 7. RT-PCR test }\end{array}$ & $\begin{array}{l}\text { 1. Minimize laparoscopic procedures } \\
\text { 2. Minimize number of operating surgeons } \\
\text { 3. Emergent cancer cases with COVID-19: } \\
\text { avoid multiple stops and all care } \\
\text { (intubation/extubation, etc.) provided in the } \\
\text { operating room }\end{array}$ & $\begin{array}{l}\text { 1. Early discharge planning } \\
\text { 2. Daily virtual visit after discharge }\end{array}$ \\
\hline Europe & $\begin{array}{l}\text { 1. Triage patients for systemic treatment } \\
\text { where feasible }\end{array}$ & $\begin{array}{l}\text { 1. FFP2 masks } \\
\text { 2. Double gloves } \\
\text { 3. Restricted the number of Anesthesiology } \\
\text { staff in the OR }\end{array}$ & - \\
\hline India & $\begin{array}{l}\text { 1. RT-PCR test } \\
\text { 2. Restrictive visitor policy } \\
\text { 3. Spacing of beds }\end{array}$ & $\begin{array}{l}\text { 1. Minimum staff in the OR } \\
\text { 2. Plastic barriers during intubation } \\
\text { 3. Smoke evacuators } \\
\text { 4. Low pressure pneumoperitoneum } \\
\text { 5. Use of Sodium hypochlorite solutions in } \\
\text { suction bottles } \\
\text { 6. Surgeons to leave room before extubation } \\
\text { 7. PPE usage } \\
\text { 8. Fiberoptic intubations }\end{array}$ & $\begin{array}{l}\text { 1. Restricted visitor policy } \\
\text { 2. Social distancing } \\
\text { 3. Spacing between beds } \\
\text { 4. Re-testing for COVID-19 as } \\
\text { needed or for patients after } 12 \text { days } \\
\text { 5. Reduce in-hospital stay } \\
\text { 6. ERAS protocols } \\
\text { 7. Modified chemotherapy regimens }\end{array}$ \\
\hline Israel & 1. Mandatory RT-PCR test & $\begin{array}{l}\text { 1. N95 and face shields for all staff during } \\
\text { intubation }\end{array}$ & - \\
\hline Italy & - & 1. FFP 2 masks & $\begin{array}{l}\text { 1. COVID-19 testing for patients with } \\
\text { fevers }\end{array}$ \\
\hline Japan & $\begin{array}{l}\text { 1. Screening test for SARS-CoV-2 } \\
\text { 2. Screening chest CT } \\
\text { 3. Restricted visitor policy }\end{array}$ & $\begin{array}{l}\text { 1. Full universal precautions if patient } \\
\text { confirmed with COVID-19 diagnosis }\end{array}$ & $\begin{array}{l}\text { 1. Mask usage after surgery for } \\
\text { patients }\end{array}$ \\
\hline
\end{tabular}


Table 2 (continued)

\begin{tabular}{|c|c|c|c|}
\hline $\begin{array}{l}\text { Country/ } \\
\text { region }\end{array}$ & Preoperative & Intraoperative & Postoperative \\
\hline $\begin{array}{l}\text { Republic of } \\
\text { Korea }\end{array}$ & $\begin{array}{l}\text { 1. RT-PCR test } \\
\text { 2. Infrastructure modifications to } \\
\text { accommodate for COVID-19 patients }\end{array}$ & $\begin{array}{l}\text { 1. If confirmed or suspected of COVID-19- } \\
\text { PPE usage with facemask/goggles and } \\
\text { other universal precautions } \\
\text { 2. OR with negative pressure } \\
\text { 3. Powered air-purifying respirator (PAPR) }\end{array}$ & $\begin{array}{l}\text { 1. Restrictive visitor policy } \\
\text { 2. New Nursing system to take care of } \\
\text { patients and reduce family } \\
\text { members }\end{array}$ \\
\hline Mexico & $\begin{array}{l}\text { 1. RT-PCR test } \\
\text { 2. CT chest } \\
\text { 3. Evaluation for COVID-19 symptoms }\end{array}$ & $\begin{array}{l}\text { 1. More outpatient surgical procedures } \\
\text { 2. More procedures under regional anesthesia } \\
\text { 3. Specific intubation protocols } \\
\text { 4. Specific OR's for COVID-19 positive } \\
\text { patients }\end{array}$ & - \\
\hline Pakistan & $\begin{array}{l}\text { 1. Chest X ray } \\
\text { 2. RT-PCR test } \\
\text { 3. Clinical screening for COVID-19 }\end{array}$ & $\begin{array}{l}\text { 1. OR with negative pressure } \\
\text { 2. Lowest setting for electrocautery } \\
\text { 3. Dedicated OR for COVID-19 patients } \\
\text { 4. PPE for all during procedures with general } \\
\text { anesthesia } \\
\text { 5. Minimize personnel in OR, particularly } \\
\text { during intubation/extubation } \\
\text { 6. OR doors closed at all times } \\
\text { 7. Smoke evacuators for electrocautery } \\
\text { 8. Extra precautions for laparoscopic } \\
\text { procedures }\end{array}$ & $\begin{array}{l}\text { 1. Enhanced monitoring for COVID- } \\
19 \text { with repeat RT-PCR test as } \\
\text { needed } \\
\text { 2. Separate rooms for patients with } \\
\text { suspected COVID-19 } \\
\text { 3. If COVID-19 confirmed-involved } \\
\text { healthcare workers isolated for } 14 \\
\text { days and patient moved to special } \\
\text { units } \\
\text { 4. Restricted visitor policy }\end{array}$ \\
\hline $\begin{array}{l}\text { United } \\
\text { States of } \\
\text { America }\end{array}$ & $\begin{array}{l}\text { 1. COVID-19 testing pre op } \\
\text { 2. Consider non-operative approaches } \\
\text { with increase in neo-adjuvant therapy } \\
\text { 3. Minimize cases that would need ICU } \\
\text { stay or overnight stay }\end{array}$ & $\begin{array}{l}\text { 1. Dedicated OR for COVID- } 19 \text { patients } \\
\text { 2. PPE usage }\end{array}$ & $\begin{array}{l}\text { 1. Restricted visitor policy } \\
\text { 2. Promote out-patient surgery } \\
\text { 3. Promote telehealth follow up }\end{array}$ \\
\hline
\end{tabular}

$E R A S$ enhanced recovery after surgery, $P A C U$ Post Anesthesia Care Unit, $P P E$ personal protective equipment, $A G P$ aerosol-generating procedures, $O R$ operating room, $I C U$ intensive care unit

This is due to multiple factors ranging from: reducing screening for cancer, such as breast/colorectal, etc., lack of screening leading to presentation of cancers at more advanced stages of disease, delayed or cancelled surgical procedures, and inability to offer other treatment options when surgery is cancelled. Many respondents noted that they are already witnessing an increase in the numbers of patients with advanced stages of disease. Leaders from places where surgical care was resumed quickly felt that the impact on long-term prognosis may be minimal.

\section{Impact on Research and Education}

The majority of respondents noted a significant negative impact on surgical research due to various factors: preferential allocation of all resources to address the COVID-19 pandemic and inability to or slowdown of recruitment of patients into trials due to lack of or reduced patient contact (Table 3). Some noted that established trials were allowed to continue with or without modifications, albeit at a slower pace with a pause on initiation of new trials. Paradoxically, some responded that they found more time to conduct research not requiring direct clinical input. Although there was a reduction in the overall level of research activity, the majority noted that they initiated new research protocols or trials related to the impact of COVID-19 on cancer care.

Similarly, the majority of respondents expressed a concern of the significant impact on surgical education. For many of the countries/regions, education was transitioned to virtual formats. Education in the OR was significantly disrupted due to the precautionary reduction in the number of personnel permitted, which by hierarchical default affected trainees the most. Some countries felt the need to arrange dedicated workshops to make up for the loss of months of surgical skill training. Although the impact on education was felt to be significant, many noted that they were able to return to pre-pandemic educational routines within a few months.

The impact on ancillary domains of cancer care during the COVID-19 pandemic is documented in Table 4. Not 
TABLE 3 Impact on research and education

\begin{tabular}{|c|c|c|c|}
\hline $\begin{array}{l}\text { Country/ } \\
\text { region }\end{array}$ & Impact on research in general & $\begin{array}{l}\text { Initiated new } \\
\text { COVID-19 related } \\
\text { research protocols- } \\
\text { yes/no }\end{array}$ & Impact on surgical education \\
\hline Brazil & $\begin{array}{l}\text { 1. Significant effect due to all efforts being } \\
\text { diverted to address COVID-19/lack of } \\
\text { interactions with patients }\end{array}$ & Yes & $\begin{array}{l}\text { 1. Significant impact for } 6 \text { months with transition to } \\
\text { virtual classes } \\
\text { 2. Minimized impact on surgical oncology } \\
\text { education due to efforts of BSSO }\end{array}$ \\
\hline Canada & $\begin{array}{l}\text { 1. Open trials: allowed to continue trial for } \\
\text { already enrolled patients } \\
\text { 2. Stopped enrollment of new patients } \\
\text { 3. Stopped activation of new trials } \\
\text { 4. Some protocols changed to accommodate } \\
\text { virtual visits } \\
\text { 5. Priority given to COVID-19 related research } \\
\text { 6. Trials with minimal resource requirements } \\
\text { were able to be continued }\end{array}$ & Yes & $\begin{array}{l}\text { 1. Reduction of number of learners in the OR } \\
\text { 2. Fewer learners in clinics and these were } \\
\text { transitioned to virtual format } \\
\text { 3. All didactics transitions to virtual } \\
\text { 4. Stopped away elective rotations } \\
\text { 5. Royal College examinations for first year trainees } \\
\text { transitioned to multiple choice questions only } \\
\text { with elimination of oral examination }\end{array}$ \\
\hline Chile & $\begin{array}{l}\text { 1. Research related to clinical contact was } \\
\text { stopped but noted more time to conduct } \\
\text { research that did not require patient encounters }\end{array}$ & Yes & $\begin{array}{l}\text { 1. No interruption of teaching in the intra-operative } \\
\text { setting }\end{array}$ \\
\hline China & - & No & $\begin{array}{l}\text { 1. Significant impact on medical } \\
\text { students/postgraduate students/fellows }\end{array}$ \\
\hline Egypt & $\begin{array}{l}\text { 1. Started trials with new management protocols } \\
\text { such as: short course radiation therapy/TNT }\end{array}$ & Yes & 1. Transition to virtual format \\
\hline Europe & 1. Most clinical trials were stopped & Yes & $\begin{array}{l}\text { 1. No students or observers were permitted for the } \\
\text { entirety of } 2020\end{array}$ \\
\hline India & $\begin{array}{l}\text { 1. Significant impact } \\
\text { 2. Some protocols were modified }\end{array}$ & Yes & 1. Transition to virtual format \\
\hline Israel & $\begin{array}{l}\text { 1. Minimal impact early in the pandemic but } \\
\text { subsequent impact due to diversion of research } \\
\text { resources to COVID-19 related research }\end{array}$ & Yes & $\begin{array}{l}\text { 1. Reduction of number of learners in the OR earlier } \\
\text { in the pandemic with return to normal by summer } \\
\text { of } 2020\end{array}$ \\
\hline Italy & $\begin{array}{l}\text { 1. Delay in projects due to lack of clinical } \\
\text { material }\end{array}$ & Yes & $\begin{array}{l}\text { 1. Significant impact on education as many surgical } \\
\text { departments were shut down }\end{array}$ \\
\hline Japan & $\begin{array}{l}\text { 1. Temporary disruption of patient enrolment in } \\
\text { trials }\end{array}$ & No & $\begin{array}{l}\text { 1. Medical students prohibited from entering } \\
\text { teaching hospital or University }\end{array}$ \\
\hline $\begin{array}{l}\text { Republic of } \\
\text { Korea }\end{array}$ & $\begin{array}{l}\text { 1. Decrease or stopped enrollment of patients in } \\
\text { trials }\end{array}$ & No & $\begin{array}{l}\text { 1. Significant impact early on in the pandemic with } \\
\text { return to normal patterns }\end{array}$ \\
\hline Mexico & $\begin{array}{l}\text { 1. Significant impact } \\
\text { 2. Reduction in translational research as } \\
\text { laboratories closed } \\
\text { 3. Reduction in clinical trials } \\
\text { 4. Decreased activity in the Institutional Review } \\
\text { Committee }\end{array}$ & Yes & 1. Minimal impact \\
\hline Pakistan & $\begin{array}{l}\text { 1. Some delays or slowing of patient enrolment } \\
\text { 2. Paradoxical increase in cancer research in } \\
\text { some parts } \\
\text { 3. Increase in COVID-19 related research in } \\
\text { cancer patients. }\end{array}$ & Yes & $\begin{array}{l}\text { 1. Significant impact as surgical trainees were } \\
\text { redirected to COVID-19 care resulting in loss of } \\
\text { nearly } 1 \text { year of surgical training and confidence } \\
\text { 2. Arranged dedicated workshops for junior surgical } \\
\text { residents to improve surgical skills }\end{array}$ \\
\hline $\begin{array}{l}\text { United States } \\
\text { of America }\end{array}$ & $\begin{array}{l}\text { 1. Challenges with clinical trials } \\
\text { 2. Restrictions in research personnel access to } \\
\text { campus/more research personnel working } \\
\text { from home } \\
\text { 3. Difficulties placing orders for animal research }\end{array}$ & Yes & $\begin{array}{l}\text { 1. For surgical trainees: decreased operative } \\
\text { cases/didactic conferences/and clinical rotations } \\
\text { 2. Difficulty with job searches for surgical trainees } \\
\text { 3. Cancelled clinical rotations for medical students } \\
\text { for several months }\end{array}$ \\
\hline
\end{tabular}

TNT total neoadjuvant therapy, BSSO Brazilian Society of Surgical Oncology, OR operating room 
TABLE 4 Impact on ancillary domains of cancer care during the COVID-19 pandemic

\begin{tabular}{|c|c|c|c|}
\hline $\begin{array}{l}\text { Country/ } \\
\text { region }\end{array}$ & Effect of social inequities & Financial impact on healthcare systems & $\begin{array}{l}\text { Impact on well-being of surgical } \\
\text { community }\end{array}$ \\
\hline Brazil & $\begin{array}{l}\text { 1. Delayed screening/increased wait } \\
\text { times for surgery for patients } \\
\text { accessing SUS }\end{array}$ & $\begin{array}{l}\text { 1. Public investment in cancer care } \\
\text { remained the same due to partnership } \\
\text { between the BSSO and Health Ministry }\end{array}$ & $\begin{array}{l}\text { 1. Well-being was maintained by the } \\
\text { multiple efforts of BSSO (increased } \\
\text { activities/campaigns/online events/ } \\
\text { enhance social media activities) }\end{array}$ \\
\hline Canada & $\begin{array}{l}\text { 1. Yet to be determined but anecdotally } \\
\text { worse outcomes for LSES patients }\end{array}$ & $\begin{array}{l}\text { 1. Significant but the full impact is yet to } \\
\text { be determined }\end{array}$ & $\begin{array}{l}\text { 1. Personal and professional stress and } \\
\text { burnout related to fear, uncertainty, } \\
\text { unpredictable work patterns and } \\
\text { reduced remuneration }\end{array}$ \\
\hline Chile & $\begin{array}{l}\text { 1. LSES patients fared worse due to lack } \\
\text { of access to care and information } \\
\text { regarding COVID-19 }\end{array}$ & $\begin{array}{l}\text { 1. Reduction in income for private } \\
\text { surgeons by almost } 50 \% \text {. } \\
\text { 2. It is likely that the government will } \\
\text { increase funding for healthcare in the } \\
\text { future }\end{array}$ & $\begin{array}{l}\text { 1. Some stress due to uncertainty but also } \\
\text { a paradoxical increase in the sense of } \\
\text { duty and fulfilment }\end{array}$ \\
\hline China & - & 1. Decreased income & - \\
\hline Egypt & $\begin{array}{l}\text { 1. Not applicable as all patients have } \\
\text { access to NHS and Insurance } \\
\text { 2. Satellite centers in rural and remote } \\
\text { areas helped to alleviate the situations }\end{array}$ & $\begin{array}{l}\text { 1. Additional COVID-19 related } \\
\text { measures increased the cost of cancer } \\
\text { care which was partially offset by } \\
\text { budget readjustments and extra } \\
\text { financial aid from the government and } \\
\text { donations }\end{array}$ & - \\
\hline Europe & $\begin{array}{l}\text { 1. The presence of NHS did not } \\
\text { aggravate any of the pre-existing } \\
\text { disparities }\end{array}$ & $\begin{array}{l}\text { 1. Significant but the full impact is yet to } \\
\text { be determined }\end{array}$ & $\begin{array}{l}\text { 1. Stress of patient care is now } \\
\text { manifesting in many surgeons/nurses } \\
\text { leaving jobs }\end{array}$ \\
\hline India & $\begin{array}{l}\text { 1. Compromised care for LSES due to } \\
\text { multiple issues such as: financial } \\
\text { constraints/transportation issues/rural } \\
\text { locations of many patients }\end{array}$ & $\begin{array}{l}\text { 1. } 1 \text { Significant loss of revenue which } \\
\text { was worsened by the increased costs } \\
\text { related to additional COVID-19 related } \\
\text { precautions/measures }\end{array}$ & $\begin{array}{l}\text { 1. Significant impact early on due to fear } \\
\text { of uncertainty and COVID-19 infection } \\
\text { in some surgical personnel. } \\
\text { 2. Morale recovered within a short period } \\
\text { of time } \\
\text { 3. Regular counselling in small } \\
\text { groups/motivating messages through } \\
\text { WhatsApp and group emails } \\
\text { 4. Increase in sense of pride and } \\
\text { determination helped as well }\end{array}$ \\
\hline Israel & $\begin{array}{l}\text { 1. Lower vaccination rates for areas with } \\
\text { lower economic status }\end{array}$ & $\begin{array}{l}\text { 1. Initial loss of revenue was subsequently } \\
\text { and near completely addressed through } \\
\text { the enhanced efforts and funding from } \\
\text { the Ministry of Health (increasing staff } \\
\text { positions/ICU beds/sustaining cancer } \\
\text { care despite the pandemic) }\end{array}$ & $\begin{array}{l}\text { 1. Inability to travel and interact with } \\
\text { peers/friends may have affected level } \\
\text { and standard of care } \\
\text { 2. No specific measures were undertaken }\end{array}$ \\
\hline Italy & 1. No effect & 1. Present but difficult to calculate & 1. No specific measures were undertaken \\
\hline Japan & 1. No effect & $\begin{array}{l}\text { 1. Support from the government negated } \\
\text { any adverse financial impact }\end{array}$ & $\begin{array}{l}\text { 1. No impact on well-being and no } \\
\text { specific measures were undertaken }\end{array}$ \\
\hline $\begin{array}{l}\text { Republic of } \\
\text { Korea }\end{array}$ & $\begin{array}{l}\text { 1. Due to the presence of public } \\
\text { insurance for all, social inequities did } \\
\text { not affect care } \\
\text { 2. Initial drop in screenings for LSES } \\
\text { patients was returned to normal by } \\
\text { enhanced governmental efforts }\end{array}$ & $\begin{array}{l}\text { 1. Significant impact but equally } \\
\text { significant compensation from the } \\
\text { government may have contributed to } \\
\text { net equal situation with no major } \\
\text { financial losses }\end{array}$ & $\begin{array}{l}\text { 1. Decrease in morale and well-being due } \\
\text { to social distancing and meeting bans } \\
\text { 2. Being addressed by conducting } \\
\text { academic meetings online and holding } \\
\text { small gatherings }\end{array}$ \\
\hline Mexico & 1. No effect & $\begin{array}{l}\text { 1. Greater impact on governmental } \\
\text { institutions }\end{array}$ & $\begin{array}{l}\text { 1. Significant impact due to anxiety, } \\
\text { burnout, posttraumatic stress and } \\
\text { depression } \\
\text { 2. Addressed by providing counseling } \\
\text { services online and in-person }\end{array}$ \\
\hline Pakistan & $\begin{array}{l}\text { 1. The pandemic aggravated the pre- } \\
\text { existing disparities in cancer care }\end{array}$ & $\begin{array}{l}\text { 1. Increased costs of care to address } \\
\text { patients presenting in more advanced } \\
\text { stages of disease }\end{array}$ & $\begin{array}{l}\text { 1. Fear of contracting disease affected the } \\
\text { moral of trainees. }\end{array}$ \\
\hline
\end{tabular}


Table 4 (continued)

\begin{tabular}{|c|c|c|c|}
\hline $\begin{array}{l}\text { Country/ } \\
\text { region }\end{array}$ & Effect of social inequities & Financial impact on healthcare systems & $\begin{array}{l}\text { Impact on well-being of surgical } \\
\text { community }\end{array}$ \\
\hline & $\begin{array}{l}\text { 2. LSES patients that seek care in public } \\
\text { health care systems were affected the } \\
\text { most } \\
\text { 3. Privately insured patients were able to } \\
\text { access care albeit at a higher price } \\
\text { 4. Funding from federal government/ } \\
\text { NGO's and private philanthropists } \\
\text { was instrumental in blunting the } \\
\text { impact }\end{array}$ & $\begin{array}{l}\text { 2. Costs increased in both public and } \\
\text { private health care systems }\end{array}$ & $\begin{array}{l}\text { 2. Leading from the front, maintaining } \\
\text { the team dynamics and training } \\
\text { opportunities, providing adequate time } \\
\text { off were helpful in improving morale }\end{array}$ \\
\hline $\begin{array}{l}\text { United } \\
\text { States of } \\
\text { America }\end{array}$ & $\begin{array}{l}\text { 1. Awareness and increased } \\
\text { responsiveness to the underserved } \\
\text { 2. Yet to be assessed impact due to } \\
\text { social inequities }\end{array}$ & $\begin{array}{l}\text { 1. Employee separation and pay cuts in } \\
2020 \text { but rebounded strongly in } 2021 \\
\text { 2. Loss of income due to reduced } \\
\text { procedures which was counterbalanced } \\
\text { by government funding }\end{array}$ & $\begin{array}{l}\text { 1. Morale strong in some places due to } \\
\text { teamwork although some burnout was } \\
\text { evident } \\
\text { 2. Many willing to work at front lines } \\
\text { beyond their primary scope of work or } \\
\text { training } \\
\text { 3. Lack of face-to-face interactions and } \\
\text { prolonged impact of the pandemic has } \\
\text { been depressing }\end{array}$ \\
\hline
\end{tabular}

SUS Brazilian Public Health System (Sistema Único de Saúde, or SUS), BSSO Brazilian Society of Surgical Oncology, LSES lower socioeconomic strata, NHS National Health System/Service, ICU intensive care unit

surprisingly, patients from the lower socio-economic strata (LSES) in some countries were affected the most due to delays in screening and care. LSES patients traditionally access the public health systems which were hit harder in these aforesaid countries. As of result of the heightened impact on the public health care systems, some noted a worsening of the preexisting disparities in cancer care for LSES patients. Some countries did not notice any detrimental effect, which was particularly noted in countries that had any type of preexisting robust National Health Service/System (NHS) in place for health care delivery.

Many countries/regions noted a significant financial impact related to loss of revenue combined with an increase in costs to deliver care in the COVID-19 environment. In some countries, governmental aid was instrumental in compensating for the financial losses resulting in a net neutral situation. Some other countries acknowledged the significant financial effects but the full impact is yet to be determined.

The COVID-19 pandemic had a significant impact on the morale and well-being of the surgical community due to many reasons, such as: fear of the unknown, unpredictable work patterns, reduced remuneration, inability to travel and interact with peers, and social isolation. Several respondents noted that they proactively implemented measures to improve well-being and morale, such as: increasing support through professional societies, increasing online interactions and social media activities, providing counseling (online and in-person) services, maintaining normalcy as much as possible, and providing adequate time off.

\section{Lessons Learned and Strategies for the Future are Documented in Table 5}

Some of the respondents noted that cancellation of cancer surgical procedures must be avoided at any cost. This would obviously depend on the presence of prior care platforms that help to plan, anticipate, and implement alternative treatment pathways when forced to cancel planned elective cancer operations. The role and importance of multidisciplinary teams in determining alternative treatment strategies also was highlighted as was the collaborative spirit between surgical, medical, and radiation oncologists. Several respondents felt that they found new appreciation for the resilience displayed by cancer professionals even under the duress of a pandemic. Some respondents emphasized other lessons, such as: improving efficiency in screening, developing triage algorithms, exploiting the value of ambulatory care platforms, promoting virtual platforms for patient care and education, obtaining real-time data on COVID-19 burden, and the value of assisted funding from government to help cope with the pandemic.

Several strategies were suggested to help prepare for any future catastrophic events. Creating dedicated units/ 
TABLE 5 Lessons learned and strategies for the future

\begin{tabular}{lll}
\hline $\begin{array}{l}\text { Country/ } \\
\text { region }\end{array}$ & Lessons learned & Strategies for the future \\
\hline Brazil & $\begin{array}{l}\text { 1. Detrimental effects of halting cancer surgical procedures } \\
\text { 2. Hitherto underappreciated resilience of cancer surgeons came to } \\
\text { light and they need to be supported by their respective Societies }\end{array}$ & $\begin{array}{l}\text { 1. Create dedicated units/hospitals to cater exclusively } \\
\text { for cancer care and thereby avoid interruptions in } \\
\text { care }\end{array}$ \\
& $\begin{array}{l}\text { 3. Vigilance to address the consequences of the pandemic } \\
\text { 2. Cross-pollination of best and worst practices between } \\
\text { various surgical oncology societies across the world }\end{array}$ \\
& $\begin{array}{l}\text { 1. Vital to have prioritization strategies a priori } \\
\text { 2. Ability to make decisions for treatment alterations under resource } \\
\text { constraints }\end{array}$ & $\begin{array}{l}\text { 3. Vigilance regarding false information } \\
\text { 1. Advocate and support our patients, particularly those } \\
\text { vulnerable to societal/economic inequities }\end{array}$ \\
& $\begin{array}{l}\text { 3. Collaborative spirit of medical and radiation oncologists } \\
\text { 4. Virtual care platforms need to be developed for postoperative care }\end{array}$ & $\begin{array}{l}\text { 3. Support (education and psychological) for surgical } \\
\text { oncologists as well through webinars, etc. }\end{array}$
\end{tabular}

Chile $\quad$ 1. Need universal health care

1. Universal access to health care

2. Demonstrated that we can a lot even with minimal resources

2. Strengthen healthcare systems

China 1. Importance of personal protection

2. Witnessed the efficiency of public health care system

Egypt 1. To have strategies in place for alternative treatment plan when surgery cannot be performed

2. Financial/logistical back up plans need to be in place

3. Explore the role of virtual and telemedicine for patient care and education

Europe 1 . Robust, multidisciplinary platforms to divert patients to alternative treatment pathways when planned surgical procedure are cancelled or postponed

2. Enhance the role of ambulatory cancer surgery programs

3. Enhance the role of simulation-based training for surgical trainees

India 1. Stringent and rapid screening and safety protocols

2. Guideline-based alteration in surgical treatment plans

3. Enhance the role of ERAS protocols

Israel Avoid screening delays to avoid delays in diagnosis

2. Back up plans in place to avoid cancellation of cancer surgical procedures

3. Critical role of government funding to maintain cancer surgery during catastrophic events

Italy $\quad 1$. Cancer surgical procedures should not be put on hold

Japan 1. Obtain accurate information about burden of COVID-19

2. Ensure adequate supply of PPE, ICU beds, and healthcare workers

1. Create dedicated units/hospitals to continue cancer care uninterrupted

1. Maintain vigilance to activate emergency protocols

2. Coordinate with regional centers to share the burden of care during catastrophic events

3. Create local stockpiles of PPE, drugs, and other medical equipment to be used for future events

Republic of 1. Adequate preparation with equipment and facilities to deal with Korea patients during infectious disease-related catastrophic events

1. Both patients and physicians to maintain hand hygiene and masks during interactions

2. Strategies in place to determine sequence of deployment of personnel and resources

2. Liberal use of PPE, double gloves, face masks, googles, etc. 
Table 5 (continued)

\begin{tabular}{|c|c|c|}
\hline $\begin{array}{l}\text { Country/ } \\
\text { region }\end{array}$ & Lessons learned & Strategies for the future \\
\hline & 3. Enhance the role of online educational platforms & $\begin{array}{l}\text { 3. Plans in place with alternative treatment strategies in } \\
\text { case of cancellation of surgical procedures }\end{array}$ \\
\hline Mexico & $\begin{array}{l}\text { 1. Promote strategic teamwork } \\
\text { 2. Incorporate compassion }\end{array}$ & 1. Be vigilant and prepared \\
\hline Pakistan & $\begin{array}{l}\text { 1. Promote teamwork to help each other and maintain morale } \\
\text { 2. Promote safe surgical principles } \\
\text { 3. Viable communication channels to deliver information and } \\
\text { encourage counselling services } \\
\text { 4. Avoid cancellations of cancer surgical procedures }\end{array}$ & $\begin{array}{l}\text { 1. Enhance collaboration with different groups to learn } \\
\text { from each other } \\
\text { 2. Research to create preparedness protocols for any } \\
\text { future emergencies } \\
\text { 3. Focus on the safety of surgeon as well } \\
\text { 4. Strategic prioritization of surgical procedures } \\
\text { 5. Multidisciplinary management and implementation } \\
\text { of health policies to keep infectivity and fatality low } \\
\text { 6. Geography-specific research to develop evidence- } \\
\text { based guidelines to suit the local environment. }\end{array}$ \\
\hline $\begin{array}{l}\text { United } \\
\text { States of } \\
\text { America }\end{array}$ & $\begin{array}{l}\text { 1. Importance of flexibility with ability to postpone procedures with } \\
\text { likely minimal impact } \\
\text { 2. Focus on patients with a reassuring attitude } \\
\text { 3. Develop prioritizing strategies } \\
\text { 4. Maintain vigilance for COVID-19 testing } \\
\text { 5. Minimize cases that may need ICU stay }\end{array}$ & $\begin{array}{l}\text { 1. Be proactive and work on scenario planning } \\
\text { 2. Develop in-built systems to promote the ability for } \\
\text { rapid redeployment of personnel } \\
\text { 3. Safety of staff is just as important } \\
\text { 4. Memorize lessons learned from this pandemic for } \\
\text { any future events and streamline healthcare delivery } \\
\text { 5. Promote comfort to encourage people to step into } \\
\text { new roles }\end{array}$ \\
\hline
\end{tabular}

$E R A S$ Enhanced Recovery After Surgery, $P P E$ personal protective equipment, $I C U$ intensive care unit; $N A C T$ neoadjuvant chemotherapy

hospitals for cancer care may be beneficial. This can facilitate uninterrupted cancer surgical care regardless of any other detrimental factors. Promoting collaboration between the various surgical oncology societies across the world to cross pollinate best and worst practices will be beneficial. Efforts to advocate for the physical, emotional, and financial well-being of all healthcare professions should be prioritized. A heightened sense of vigilance combined with rapid initiation of back up emergency protocols can be useful in avoiding interruptions in delivery of surgical cancer care. Some felt that there could be a benefit in continuing the current precautionary practices even after the pandemic subsides. Other proposed strategies include avoiding screening delays, create local stockpiles of PPE and other equipment, and promote geography-specific research in real-time to develop evidence-based practices.

\section{DISCUSSION}

The primary and specific goal of this article is to summarize the opinions from the leaders of the GFCS about the impact of COVID-19 pandemic on cancer surgery. The leaders of the GFCS hail from different parts of the world and represent nearly three-quarters of the global cancer burden by incidence and mortality.
The members of GFCS also hold leadership positions in the respective surgical oncology societies of their country/region. Through these leadership positions, they tend to be involved in steering and guiding the educational paradigms, research platforms, and delivery of cancer surgery in their respective geographic region/s. As a result, the opinions of these leaders on matters related to cancer surgery tend to be strategic, visionary, pragmatic, broadly applicable in scope, and extremely valuable.

It is not surprising that the leaders felt that the pandemic had a devastating effect on nearly every aspect extending from clinical care, education, and research with equally detrimental effects on well-being and financial status. Clinical care was noted to be severely compromised with delayed or canceled elective procedures due to various reasons, such as diversion of efforts to address COVID-19, lack of PPE, unpredictability of workflows, and lack of screening amongst several other factors. It is ironical to note that cancers with well-established screening strategies (breast, colorectal) were affected the most. Many felt that this degree of disruption in cancer care will have a negative prognostic impact in the long-term and may contribute to a new phenomenon of stage migration. ${ }^{13}$ Severe interruptions also were noted in delivery of education and conduct of research. 
The increased costs associated with delivering care under new/extra precautions combined with lost revenue resulting from fewer surgical procedures had a major financial impact on individual surgeons as well as hospitals. The fear of uncertainty, extremely unpredictable work schedules, social isolation, and inability to interact with peers on a regular basis adversely impacted the well-being of surgeons as well as every other health profession.

Despite the persistent duress of the pandemic for a prolonged period, there were some redeeming aspects highlighted as well. Many appreciated the hitherto underappreciated, dynamism, adaptability, and resilience of the surgical oncology community and witnessed the true spirit of collaboration with our colleagues in medical and radiation oncology. Although research overall was severely compromised, this pandemic provided a new opportunity for research related to COVID-19 and cancer surgery, which may be beneficial for any future catastrophic events. The additional funding provided by the respective governments served as lifelines during the pandemic. The pandemic also highlighted the benefits of collaboration between individuals and surgical oncology societies across the world to cross-pollinate the best and worst practices.

There are several limitations to this paper. It is based exclusively on the opinions of surgical oncologists rather than on any prospective or retrospective study design. Although the members of the GFCS hold leadership roles, it is likely that their opinions may not represent the views, outcomes, and practices of the entirety of the country or region they represent. Similarly, it is not clear why some cancers were affected more than others. It could be a reflection of various factors, such as the availability of specific resources, complexity of treatment required, availability of adjuvant options, and aggressive or indolent nature of each specific cancer.

It was felt by everyone at the virtual meeting that we need to develop strategies to guide the global surgical oncology community. These strategies will be extremely helpful to guide cancer surgeons, hospitals, policy makers, and governments across the world to deliver uninterrupted surgical care for cancer patients in the event of another catastrophic event in the future. The Global Forum of Cancer Surgeons is well suited for this purpose and will embark on this as its next initiative.
DISCLOSURE Douglas Tyler: up to date royalties for writing section, Castle Bioscience Honorarium for participation in scientific advisory board $\$ 1500$ 11/22/20.

\section{REFERENCES}

1. https://coronavirus.jhu.edu/map.html. Accessed October 24, 2021

2. https://www.who.int/news-room/spotlight/the-impact-of-covid-1 9-on-global-health-goals. Accessed October 24, 2021

3. https://www.cdc.gov/coronavirus/2019-ncov/variants/variant-inf o.html. Accessed October 24, 2021

4. https://cdn.who.int/media/docs/default-source/ncds/ncd-covid-19 /for-web-rapid-assessment-29-may-2020-(cleared)_125bf3849333-40c9-aab2-c0ecafb76ab2.pdf?sfvrsn=6296324c_20. Accessed October 24, 2021

5. Riera R, Bagattini AM, Pacheco RL, Pachito DV, Roitberg F, Ilbawi A. Delays and disruptions in cancer health care due to COVID-19 pandemic: Systematic review. JCO Global Oncol. 2021;7:311-23.

6. COVIDSurg Collaborative. Effect of COVID-19 pandemic lockdowns on planned cancer surgery for 15 tumor types in 61 countries: an international, prospective, cohort study. Lancet Oncol. 2021. Oct 5th, 2021. https://doi.org/10.1016/S1470-2045 (21)00493-9

7. Are C, Coit DG, McMasters KM, Giuliano AE, Anderson BO, Balch CM, et al. Global forum of cancer surgeons: declaration of intent. Ann Surg Oncol. 2017;24:2429-31.

8. Are C, McMaster KM, Giuliano A, Balch C, Anderson BO, Berman R, et al. Global Forum of Cancer Surgeons: a steady voice for cancer surgeons to improve surgical care for cancer patients globally. Ann Surg Oncol. 2018;25:2114-6.

9. https://www.surgonc.org/global-outreach/global-forum-of-cancer -surgeons/. Accessed October 24, 2021

10. Are C, McMasters KM, Giuliano A, Yanala U, Balch C, Anderson BO, et al. Global Forum of Cancer Surgeons: perspectives on barriers to surgical care for cancer patients and potential solutions. Ann Surg Oncol. 2019;26:1577-82.

11. Are C, Bartlett DL, Nissam A, Dov Z, Gupta A, Savant D, et al. Global Forum of Cancer Surgeons: position statement to promote cancer surgery globally. Ann Surg Oncol. 2020;27:2573-6.

12. Oliveira AF, Quadros CA, de Castro Ribeiro HS, Wainstein AJA, de Queiroz Sarmento BJ, Lyra J, et al. Global forum of cancer surgeons: support for the brazilian society of surgical oncology journey towards implementation of cytoreductive surgery/hyperthermic intraperitoneal chemotherapy in Brazil. Ann Surg Oncol. 2021;28:1892-5.

13. Are C. COVID-19 stage migration (CSM): a new phenomenon in oncology. Indian J Surg Oncol. 2021;12:1-2.

Publisher's Note Springer Nature remains neutral with regard to jurisdictional claims in published maps and institutional affiliations. 